\title{
China and Peacekeeping: Unfolding the Political and Legal Complexities of an Ambivalent Relationship
}

\author{
Mauro BARELLI \\ The City Law School - City, University of London, London, United Kingdom \\ Email: Mauro.Barelli.1@city.ac.uk
}

(Received 28 July 2021; revised 8 November 2021; accepted 16 November 2021;

first published online 20 January 2022)

\begin{abstract}
In the past decade China's engagement with UN peacekeeping has intensified. In particular, Beijing has supported and participated in peace operations that were not fully compatible with the consensual, impartial, and non-coercive models of peacekeeping traditionally employed by the United Nations. China's endorsement of offensive and intrusive missions is not inconsequential, given that it clashes with its professed adherence to rigid interpretations of the principles of sovereignty, non-intervention, and the non-use of force in international relations. This article suggests that to make sense of China's involvement in unconventional peacekeeping operations one must examine the broader process of foreign policy recalibration that is redefining the interests and priorities of the country as a new great power. Furthermore, by examining China's ambivalent approach to the principles that have traditionally defined the legal framework of UN peacekeeping, this article highlights the opportunities and challenges that China will face as a provider of international security.
\end{abstract}

Keyword: China; peacekeeping; collective security; use of force

In 2020, China commemorated the 30th anniversary of its participation in UN peacekeeping missions by issuing its first-ever White Paper on UN Peacekeeping. ${ }^{1}$ The document highlighted important facts and numbers regarding Beijing's growing engagement with this form of collective security. China is currently the second largest financial contributor to the UN peacekeeping budget, as well as the largest troop-contributing country among the five permanent members of the Security Council. In 2016, it set up and financially supported a unique China-UN peace and development fund that identified peacekeeping as a priority area. A year later, in the context of the newly created UN Peacekeeping Capability Readiness System, it established a rapid deployment standby force of 8,000 troops. That the relationship between China and peacekeeping is on an upward trajectory is further confirmed by the fact that, only recently, Beijing has started dispatching combat units to UN missions, and showing an increasing appetite for senior positions in the UN's peace and security architecture. ${ }^{2}$

\footnotetext{
${ }^{1}$ China's Armed Forces: 30 Years of UN Peacekeeping Operations, The State Council Information Office of the People's Republic of China (2020).

${ }^{2}$ Logan PAULEY, "China Takes the Lead in UN Peacekeeping" The Diplomat (17 April 2018), online: The Diplomat <https://thediplomat.com/2018/04/china-takes-the-lead-in-un-peacekeeping/>; Richard GOWAN,

(c) The Author(s), 2022. Published by Cambridge University Press. This is an Open Access article, distributed under the terms of the Creative Commons Attribution licence (https://creativecommons.org/licenses/by/4.0/), which permits unrestricted re-use, distribution, and reproduction in any medium, provided the original work is properly cited.
} 
China's relationship with UN peacekeeping, however, has not always been so idyllic. ${ }^{3}$ After becoming a member of the United Nations, Beijing was rather sceptical of the motives behind peacekeeping efforts. Accordingly, it avoided providing any support, be it financial, institutional, or practical, to the establishment of peace operations. It was China's gradual integration with the UN and the broader international system that fundamentally, but slowly, transformed its approach. Paradoxically, Beijing's enthusiasm reached its peak in the last decade when peace operations - in contrast with China's principled commitment to use peaceful means to solve conflict situations - have become considerably more aggressive in nature, moving away from the neutral and non-coercive model of peacekeeping that had been historically embraced by the UN. At about the same time, in a move that clashes with its typically rigid interpretation of the principle of sovereignty, China has also supported operations that did not necessarily enjoy the support of the state concerned.

This article examines the political complexities of these apparently contradictory developments in conjunction with a discussion of China's evolving approach to the principles that have traditionally defined the legal architecture of UN peacekeeping; that is, the consent of the parties, impartiality, and non-use of force except in self-defence. While the continued existence of these principles as guiding principles of UN peacekeeping is not contested, their meanings lend itself to different interpretations. Formally, China clings to a traditional understanding of these principles with a view to keeping them aligned with broader notions of sovereignty, non-intervention, and non-use of force, the respect of each of which Beijing considers crucial for the maintenance of stable international relations. China's rhetoric, however, is not reflective of its practice, which instead shows support for peace operations that do not conform to ideas of impartiality and defensive force, and allows for a more flexible application of the parameters of the principle of consent.

In light of the above, this article advances two main arguments. First, that China's choice to support "offensive" and "intrusive" peacekeeping operations must be understood in the context of the broader process of foreign policy recalibration that is not only redefining the interests and priorities of the country, but also reshaping its practical approach to questions of sovereignty, non-intervention, and use of force. Second, that the revealed discrepancy between rhetoric and practice reflects the opportunities and challenges that China will face as a provider of international security. The way in which China will respond to the latter will not only contribute to shape its identity, but can also have important implications for both the future of international security efforts and the legal framework of UN peacekeeping.

The rest of this article will proceed by presenting an overview of the evolution of UN peacekeeping from a Chinese perspective. It will then examine the main forces that are driving China towards taking a more active role in peacekeeping efforts. Finally, it will analyse Beijing's interpretation and application of the classic principle of peacekeeping with a view to highlighting the challenges that China will face in trying to reconcile the endorsement of offensive and intrusive operations with its continued adherence to a strict interpretation of the principles of sovereignty, non-intervention, and non-use of force.

\footnotetext{
“China's Pragmatic Approach to UN Peacekeeping” Brookings (14 September 2020), online: Brookings <https:// www.brookings.edu/articles/chinas-pragmatic-approach-to-un-peacekeeping/>.

${ }^{3}$ See, among others, Stefan STÄHLE, “China's Shifting Attitude towards United Nations Peacekeeping Operations" (2008) 195 The China Quarterly 631; LIU Tiewa, "Marching for a More Open, Confident and Responsible Great Power: Explaining China's Involvement in UN Peacekeeping Operations” (2009) 13 Journal of International Peacekeeping 101; and HE Yin, "China's Doctrine on UN Peacekeeping” in Cedric DE CONING, Chiyuki AOI, and John KARLSRUD, eds., UN Peacekeeping Doctrine in a New Era: Adapting to Stabilisation, Protection and New Threats (London: Routledge, 2017), 109.
} 


\section{The Evolution of UN Peacekeeping Operations: A Chinese Perspective}

Not expressly mentioned in the UN Charter, peacekeeping emerged as an experiment by the United Nations to reinforce its system of collective security. Before long, it became one of the most important measures adopted by the Security Council in the exercise of its primary responsibility for the maintenance of international peace and security. ${ }^{4}$ The first team of UN observers was deployed to the Middle East following the end of the 1948 Arab-Israeli War, while the earliest armed peacekeeping operation was established in 1956 to secure and supervise the cessation of hostilities in the Suez Canal (UNEF I). Since then, over a million peacekeepers have served under the UN flag in more than 70 missions. ${ }^{5}$ The inherent characteristics of peacekeeping contribute to explaining its global success. Classic peacekeeping, typically associated with situations of inter-state conflict, is designed to maintain ceasefires and assist in implementing peace agreements. This model of peacekeeping is based on three core principles, namely: consent of the parties (including the consent of the host state), impartiality, and the non-use of force except in self-defence. The importance of these principles, which were first affirmed following the establishment of UNEF I, ${ }^{6}$ lies in the fact that they define a non-interventionist and non-coercive typology of peacekeeping which sits comfortably within the legal framework of the UN Charter. Indeed, the trinity of peacekeeping reflects precisely the fundamental principles of international law endorsed by Article 2 of the Charter; that is, sovereignty, non-intervention, and the non-use of force. ${ }^{7}$ Another important observation stems from the above. While certainly representing a more forceful technique of solving disputes than those expressly enunciated in Chapter VI, classic peacekeeping is fundamentally different from Security Council action taken under Chapter VII of the UN Charter, which is nonimpartial, non-consensual, and coercive in nature.

There is little doubt that this model of peacekeeping is fully compatible with China's vision of the international system as a sovereignty-centered structure. On the one hand, the requirement to obtain the consent of the host state to the deployment of a peacekeeping mission guarantees the respect of the principles of sovereignty and non-intervention which, as will be discussed in the next section, represent for China the building blocks of international law and relations. On the other hand, the use of defensive force satisfies Beijing's preference to deal with conflict situations through diplomatic channels, while treating the use of force, even when authorized by the Security Council, as an absolute last resort. For these reasons, following an initial period of complete disengagement, derived largely from a broader sense of mistrust towards the UN system as a whole, in the early 1980s China began to show support for the UN peacekeeping system. Under this new trend, facilitated by a broader effort to redefine its relationship with the international community, Beijing began to contribute to the UN peacekeeping budget as well as to vote in favour of some missions while acquiescing to the establishment of others. Gradually, these timid forms of endorsement led to the more explicit recognition of peacekeeping as an important and legitimate tool for international peace and security, opening the door to China's active participation in these operations. Thus, while the early 1990s witnessed the deployment of China's first personnel to UN missions, in the

\footnotetext{
${ }^{4}$ United Nations Peacekeeping Operations: Principles and Guidelines, the Capstone Doctrine, UN Department of Peacekeeping Operations and Department of Field Support (2008) ("Capstone") at 17.

${ }^{5}$ Data available at United Nations Peacekeeping, online: United Nations <https://peacekeeping.un.org/en>.

${ }^{6}$ UNEF: Summary Study of the Experience Derived from the Establishment and Operation of the Force, Report of the Secretary-General, UN General Assembly Official Records, 13th Session, UN Doc. A/3943 (1958), at 33 (Annex 1), para. 9.

${ }^{7}$ Nicholas TSAGOURIAS and Nigel D. WHITE, Collective Security: Theory, Law and Practice (Cambridge: Cambridge University Press, 2013) at 250.
} 
subsequent decade Beijing raised the profile of its contribution by dispatching increasing numbers of enabler troops such as engineers, logisticians and medical units. ${ }^{8}$

However, as China became more comfortable with the idea of both supporting and participating in peacekeeping operations, the nature of the latter began to change substantially. Since the end of the Cold War, a growing number of peacekeepers have been deployed, in the absence of viable peace agreements, in countries torn by internal conflicts and incapable of providing adequate security to the civilian population. ${ }^{9}$ It soon became clear that, under the new circumstances, a more robust posture, combined with the willingness to distinguish between victims and aggressors, would be indispensable for a mission's success. Accordingly, notions such as "robust mandates" and "protection of civilians" began to shape a new generation of peacekeeping operations. ${ }^{10}$ This trend reached a new peak in the last decade with the establishment of what have been described as "super-robust" operations. ${ }^{11}$ Pertinent examples include the United Nations Organization Stabilization Mission in the Democratic Republic of the Congo (MONUSCO), the United Nations Multidimensional Integrated Stabilization Mission in Mali (MINUSMA), and the United Nations Mission in South Sudan (UNMISS). In 2013, the Security Council broke new ground when it created, as part of MONUSCO, an offensive combat force authorized to carry out targeted offensive operations to neutralize armed groups posing a threat to both state authority and civilian security. ${ }^{12}$ Similarly, MINUSMA was mandated in 2016, to both engage in direct operations against terrorist organizations and anticipate, deter, and counter threats to the civilian population. ${ }^{13}$ Originally established to support the newly created state of South Sudan, UNMISS was later given a strong mandate to protect civilians. The already robust nature of the mission was further reinforced in 2016, when, following an outbreak of violence, the Security Council authorized the creation of a Regional Protection Force tasked to use all necessary means to provide a secure environment in and around the capital city of Juba. ${ }^{14}$ By virtue of their methods and goals, MINUSCO, MINUSMA, and UNMISS can hardly be reconciled with the noncoercive model of peacekeeping traditionally relied on by the UN and favoured by China. In fact, the extent and nature of force used in two of these operations, that is, MINUSCO and MINUSMA, is unprecedented even when compared to post-1999 robust protection of civilians mandates. On its part, UNMISS is of special significance because it was also established and deployed in the absence of genuine consent by the South Sudanese government, a circumstance that raised important questions about the consensual nature of the operation.

Evidently, offensive and intrusive missions, such as MINUSCO, MINUSMA, and UNMISS, clash with Beijing's aversion to the use of coercive methods in tackling conflict situations, as well as reluctance to meddle in the internal affairs of other states. Contrary to what one might have expected, however, China not only actively supported the establishment of each of these three missions, but also took the unprecedented

\footnotetext{
${ }^{8}$ For a historical overview, see Courtney FUNG, "What Explains China's Deployment to UN Peacekeeping Operations?" (2016) 16 International Relations of the Asia-Pacific 409.

${ }^{9}$ Identical Letters dated 21 August 2000 from the Secretary-General to the President of the General Assembly and the President of the Security Council, The Brahimi Report, Report of the Panel on United Nations Peace Operations, UN Doc. A/55/305-S/2000/809 (2000) ("Brahimi"), at paras. 17-20.

${ }^{10}$ Security Council Resolution 1270, UN Doc. S/RES/1270 (1999).

${ }^{11}$ Marco LONGOBARDO, “'Super-Robust' Peacekeeping Mandates in Non-International Armed Conflicts under International Law” (2020) 24 Spanish Yearbook of International Law 42.

12 Security Council Resolution 2098, UN Doc. S/RES/2098 (2013).

${ }^{13}$ Security Council Resolution 2295, UN Doc. S/RES/2295 (2016).

${ }^{14}$ Security Council Resolution 2304, UN Doc. S/RES/2304 (2016).
} 
decision to dispatch combat troops to two of them, namely MINUSMA and UNMISS. The next section will seek to shed light on the reasons behind this apparent paradox, placing the relevant discussion in the broader context of China's attempt to recalibrate its foreign policy posture and priorities.

\section{Peacekeeping and Chinese Foreign Policy}

While China acknowledges that global pressures and incentives have limited the scope of sovereignty in many important ways, it rejects the argument that this erosion has called or should call into question the validity of state-centric models of international relations. ${ }^{15}$ For China, sovereignty may no longer be as absolute as it once was, but it is not in decline either; on the contrary, it is set to remain firmly at the centre of both world politics and international law. ${ }^{16}$ Accordingly, the primacy of sovereignty, which informs also the spirit of China's Five Principles of Peaceful Coexistence, ${ }^{17}$ continues to be a distinguishing feature of Chinese international legal discourse. ${ }^{18}$ This is well reflected in official policy statements and documents that regularly underline the importance of respecting both the principle of sovereignty and its corollary, the principle of nonintervention, in relations with other states. ${ }^{19}$

Applied to conflict situations, China's foreign policy posture translates into a predisposition to solve crises through peaceful and consensual mechanisms rather than coercive diplomacy, let alone military action. To an extent this approach clashes with the nature of the peacekeeping missions discussed in the previous section. To make sense of China's recent enthusiasm for more offensive and intrusive operations one must consider the broader process of foreign policy recalibration that is pushing Beijing to revisit its non-interference mantra. ${ }^{20}$ In that context, while the decision of a state to provide peacekeepers is always a function of the complex interplay between rationales (and

\footnotetext{
${ }^{15}$ XUE Hanqin, Chinese Contemporary Perspectives on International Law: History, Culture and International Law (Leiden, Boston: Martinus Nijhoff, 2012).

${ }^{16}$ See, for example, Wim MULLER, “China's Sovereignty in International Law: from Historical Grievance to Pragmatic Tool” (2013) 1 China-EU Law Journal 35; YANG Zewei, “The End of State Sovereignty? - From a Chinese Perspective" in Per SEVASTIK, ed., Aspects of Sovereignty: Sino-Swedish Reflections (Leiden, Boston: Martinus Nijhoff, 2013), 161.

${ }^{17}$ The five principles are: mutual respect for each other's territorial integrity and sovereignty; mutual nonaggression; mutual non-interference in each other's internal affairs; equality and mutual benefit; and peaceful coexistence. See Speech by WEN Jiabao, Premier of the State Council of the People's Republic of China, at Rally Commemorating the 50th Anniversary of The Five Principles of Peaceful Coexistence, "Carrying Forward the Five Principles of Peaceful Coexistence in the Promotion of Peace and Development", 28 June 2004, online: Oxford Academic at: <https://academic.oup.com/chinesejil/article-abstract/3/2/363/335690?redirectedFrom= fulltext>.

${ }^{18}$ WANG Tieya, International law in China: Historical and Contemporary Perspectives (Leiden, Boston: Brill Nijhoff, 1990); Xue, supra note 15.

${ }^{19}$ See, for example, the Position Papers of the People's Republic of China at the 71st (2016) and 72nd (2017) Sessions of the UN General Assembly, respectively at Ministry of Foreign Affairs of the People's Republic of China, "Position Paper of the People's Republic of China At the 71st Session of the United Nations General Assembly" (7 September 2016), and Ministry of Foreign Affairs of the People's Republic of China, "Position Paper of the People's Republic of China for the 72nd Session of the United Nations General Assembly" (5 September 2017). See also Ministry of Foreign Affairs of the Russian Federation, "The Declaration of the Russian Federation and the People's Republic of China on the Promotion of International Law” (25 June 2016), online: MID Russia <http:// www.mid.ru/en/foreign_policy/news/-/asset_publisher/cKNonkJE02Bw/content/id/2331698>.

${ }^{20}$ WANG Yizhou, Creative Involvement: A New Direction in China's Diplomacy (London: Routledge, 2017) and Courtney FUNG, China and Intervention at the UN Security Council: Reconciling Status (Oxford: Oxford University Press, 2019).
} 
inhibitors) related to political, economic, security, institutional, and normative concerns, ${ }^{21}$ two types of forces, one of a geopolitical and the other of a reputational character, can be singled out as being of particular importance to China. Firstly, as a world power whose prosperity and security is increasingly dependent on peaceful development and stability across the globe, China has important incentives to engage more actively in conflict prevention and resolution. Secondly, often reprimanded by its Western counterparts, China seeks to nurture the international image of a responsible state. To an important extent, actively participating in peacekeeping can contribute to achieving those two objectives by helping to protect Chinese economic interests abroad, and project the image of a country that takes the values of peace, multilateralism, and human protection seriously.

\section{A. Peacekeeping and Global Stability}

Following the program of market reforms initiated in the late 1970s by Deng Xiaoping, the economy of China has grown at an unprecedented pace and scale. As a result of this extraordinary process, China has become the second largest economy in the world, and is now playing an increasingly influential role in the global economic order. When the need to support this unprecedented economic growth began to require access to natural resources abroad, China's global footprint, inevitably and considerably, expanded. ${ }^{22}$ Yet, as a state's global footprint expands, so does its exposure to the risks and costs of international conflicts and crises, prompting a gradual alignment of national prosperity and global stability.

The realization of the necessity to protect its growing overseas interests (in the form of investments, assets, and personnel) led China to reinterpret its inward-looking notion of security in order to fully integrate within it the question of instability in strategically important locations. ${ }^{23}$ In 2004 , Hu Jintao publicly referred, for the first time, to the importance of enhancing China's capability to safeguard its interests abroad. ${ }^{24}$ In the following years, three events contributed to accelerating this policy reorientation: first, the forced evacuation of over 30,000 Chinese nationals from Libya in $2011 ;^{25}$ second, the 2012 appointment of Xi Jinping as the General Secretary of the Chinese Communist Party, who has tied the future of Chinese diplomacy to the rejuvenation of the Chinese nation; ${ }^{26}$ and, third, the launch, in 2013, of the Belt and Road Initiative, an exceptionally ambitious infrastructure project to connect China with over 60 countries in Eurasia and Africa. ${ }^{27}$ Today,

\footnotetext{
${ }^{21}$ Alex BELLAMY and Paul WILLIAMS, Providing Peacekeepers: The Politics, Challenges, and Future of United Nations Peacekeeping Contributions (Oxford: Oxford University Press, 2013).

${ }^{22}$ Elizabeth ECONOMY and Michael LEVI, By All Means Necessary: How China's Resource Quest is Changing the World (Oxford: Oxford University Press, 2014).

${ }^{23}$ Andrea GHISELLI, Protecting China's Interests Overseas: Securitization and Foreign Policy (Oxford: Oxford University Press, 2021).

${ }^{24}$ Permanent Mission of the People's Republic of China to the United Nations Office at Geneva and Other International Organisations in Switzerland, "The $10^{\text {th }}$ Conference of Chinese Diplomatic Envoys Stationed Abroad, Beijing" (August 2004), online: MFA PRC <https://www.mfa.gov.cn/ce/cegv//eng/tpxw/t156047.htm>. For a discussion, see Mathieu DUCHÂTEL, Oliver BRÄUNER, and ZHOU Hang, "Protecting China's Overseas Interests: The Slow Shift Away from Non-interference", Stockholm International Peace Research Institute, SIPRI Policy Paper No. 41, June 2014.

${ }^{25}$ Gabe COLLINS and Andrew ERICKSON, "Implications of China's Military Evacuation of Citizens from Libya" (2011) 11:4 China Brief 8, online: The Jamestown Foundation <https://jamestown.org/program/implications-ofchinas-military-evacuation-of-citizens-from-libya/>.

${ }^{26}$ YU Hongjun, "Chinese Dream and Chinese Diplomacy Guided by the Concept of Peaceful Development" in The State Council Information Office of the People's Republic of China, Interpretation on New Philosophy of Chinese Diplomacy (Beijing: China Intercontinental Press, 2012), 76.

${ }^{27}$ Ministry of Foreign Affairs of the People's Republic of China, "President Xi Jinping Delivers Important Speech and Proposes to Build a Silk Road Economic Belt with Central Asian Countries” (7 September 2013).
} 
in a marked departure from Deng Xiaoping's cardinal rule of "keeping a low profile and biding your time", new and ambitious foreign policy guidelines, based on the concept of "major country diplomacy with Chinese characteristics", have encouraged China to become more directly involved in complex international situations, and to provide a Chinese perspective to their solution. ${ }^{28}$ More importantly, Beijing now describes its overseas interests as "a crucial part of China's national interests", and also affirms, unequivocally, that one of the missions of its armed forces is to effectively protect them. ${ }^{29}$

What follows from that is that China's overseas military presence becomes an important factor in the realization of new foreign policy goals. In this respect, it is telling that, since 2009, China's naval ships have been actively involved in the anti-piracy operations off the coast of Somalia, as mandated by the Security Council. ${ }^{30}$ This move, which represents the navy's first long-range multi-year deployment outside Chinese waters, ${ }^{31}$ served the primary purpose of protecting Chinese shipping interests in the Gulf of Aden. ${ }^{32}$ To date, the 2017 establishment of a military base in Djibouti represents the clearest indication of China's determination to project military force beyond its borders. ${ }^{33}$ These outposts can be vital to facilitate rapid deployment operations in strategic locations. However, building and maintaining them is both a costly and risky business. In addition to that, China would need to find a credible way to reconcile such an ambitious military strategy with its professed devotion to peace and non-interventionism. In this respect, the sober way in which Beijing describes its "logistical infrastructure" in Djibouti signals a certain discomfort at the prospect of being accused of pursuing global military expansion. ${ }^{34}$ In an important sense, then, peacekeeping offers a rather attractive alternative to increase China's military footprint abroad. In line with this, both the 2015 and 2019 Defence White Papers highlighted the importance of Chinese armed forces' participation in international security efforts in the context of the country's growing strategic interests. ${ }^{35}$ The fact that a significant number of peacekeeping operations have been and continue to be deployed to Africa further incentivizes China to invest in this form of collective security. This is so because Beijing has spent large amounts of political

\footnotetext{
${ }^{28}$ Ministry of Foreign Affairs of the People's Republic of China, "Exploring the Path of Major-Country Diplomacy with Chinese Characteristics, Remarks by Foreign Minister Wang Yi at the Luncheon of the Second World Peace Forum" (27 June 2013); Ministry of Foreign Affairs of the People's Republic of China, "Toward a New Type of International Relations on Win-Win Cooperation, Speech by Foreign Minister Wang Yi at Launch of the China Development Forum" (25 March 2015). For a discussion, see Bonnie S. GLASER and Alison SZALWINSKI, "Major Country Diplomacy with Chinese Characteristics" (2013) 13:16 China Brief 9 at 9-12, online: The Jamestown Foundation <https://jamestown.org/program/major-country-diplomacy-with-chinesecharacteristics/>.

${ }^{29}$ China's National Defense in the New Era, The State Council Information Office of the Peoples' Republic of China (2019); The Diversified Employment of China's Armed Forces, The State Council Information Office of the Peoples' Republic of China (2013); and China's Military Strategy, The State Council Information Office of the Peoples' Republic of China (2015).

${ }^{30}$ For example, Security Council Resolutions 1816, UN Doc. S/RES/1816 (2008), Security Council Resolutions 1846, UN Doc. S/RES/1846 (2008), and Security Council Resolutions 1851, UN Doc. S/RES/1851 (2008).

${ }^{31}$ Gisela GRIEGER, "China's Growing Role as a Security Actor in Africa”, European Parliamentary Research Service, October 2019 at 11.

${ }^{32}$ In 2019 China reported that its navy had provided security protection for over 6,600 Chinese and foreign ships and assisted over 70 ships in distress, see China's National Defense in the New Era, supra note 29, at 36.

${ }^{33}$ Jean-Pierre CABESTAN, “China's Military Base in Djibouti: A Microcosm of China's Growing Competition with the United States and New Bipolarity" (2020) 29:125 Journal of Contemporary China 731.

${ }^{34}$ See for example, LIU Caiyu, “Djibouti Base 'Not Military Expansion': MOD” (1 December 2016), online: Global Times <https://www.globaltimes.cn/content/1021149.shtml>.

${ }^{35}$ China's Military Strategy and China's National Defence in the New Era, supra note 29.
} 
and financial capital to nurture a fruitful Sino-African partnership. ${ }^{36}$ As the region emerged as a crossroad for China's investments and geopolitical interests, however, the question of regional instability prompted the need to broaden the scope of this political-economic relationship. ${ }^{37}$ To this end, in the past few years security-oriented platforms such as the China-Africa Partnership for Peace and Security Cooperation (2012) and the China-Africa Peace and Security Forum (2019) have been established to supplement the key, and economic-oriented, Forum for China-Africa Cooperation (2000). ${ }^{38}$ Not surprisingly, one of the core aspects of the emerging Sino-African security partnership has been China's pledge to support and participate in UN peacekeeping operations in the region. ${ }^{39}$ While beyond the scope of this article, it is worth noting that the imbalanced nature of the Sino-African partnership has also led to criticisms that China is exploiting the continent in an attempt to advance its global dominance. As such, these criticisms present another set of challenges for China as Beijing seeks to present its development-focused diplomacy and hands-off approach to foreign governmental affairs as better alternatives to what it describes as Western paternalistic practices. ${ }^{40}$

\section{B. Peacekeeping and Human Protection}

Contributing to UN peacekeeping efforts brings additional, non-material benefits to China. Economic growth has brought with it increasing demands that China become a responsible stakeholder. On the one hand, accusing China of being a free rider, Western counterparts demand that Beijing takes more responsibility for solving key global issues that threaten the core rules and values of an international system from which China hugely benefits. ${ }^{41}$ On the other hand, these calls reveal various degrees of concern about the "rise of China" phenomenon, particularly in relation to Beijing's presumed capacity to mount a concrete challenge to "a stable and open international system". ${ }^{2}$ Although some in China had dismissed these demands as Western attempts to hinder the rise of the country, Chinese officials have ultimately embraced the idea that with more power comes more responsibility. By accepting the costs and burden associated with being a responsible power, China seeks to achieve two correlated goals: first, to boost its moral standing both in the eyes of its own citizens and those of other countries; and, second, to disqualify the "China threat theory", which, by portraying the country as a destabilizing force in global affairs, undermines both the present and future status of China in the world. ${ }^{43}$ The acceptance of the idea of "great power responsibility" is also reflected in the

\footnotetext{
${ }^{36}$ Eleanor ALBERT, "China in Africa” Council on Foreign Relations (12 July 2017), online: Council on Foreign Relations <https://www.cfr.org/backgrounder/china-africa>.

${ }^{37}$ Barney WALSH, "China's Pervasive yet Forgotten Regional Security Role in Africa" (2019) 28: 120 Journal of Contemporary China 965.

${ }^{38}$ Abdou Rahim LEMA, “China in Africa's Peace and Security Landscape” The Diplomat (12 December 2019), online: The Diplomat <https://thediplomat.com/2019/12/china-in-africas-peace-and-security-landscape/>.

${ }^{39}$ China's Armed Forces: 30 Years of UN Peacekeeping Operations, supra note 1.

${ }^{40}$ Amitai ETZIONI, "Is China a New Colonial Power? How Well Do the Claims of Neocolonialism Stand Up?" The Diplomat (9 November 2020), online: The Diplomat <https://thediplomat.com/2020/11/is-china-a-new-colonialpower/>; HWANG Yih-Jye and Lindsay BLACK, "Victimized State and Visionary Leader? Questioning China's Approach to Human Security in Africa” (2020) 37 East Asia 1.

${ }^{41}$ See, for example, European Commission, "EU-China - A Strategic Outlook: European Commission and HR/ VP Contribution to the European Council” (12 March 2019), online: European Commission <https://ec.europa.eu/ info/sites/default/files/communication-eu-china-a-strategic-outlook.pdf> at 1.

${ }^{42}$ See, for example, The White House Washington, "Renewing America's Advantages: Interim National Security Strategic Guidance" (March 2021), online: White House <https://www.whitehouse.gov/wp-content/ uploads/2021/03/NSC-1v2.pdf> at 8.

${ }^{43}$ Randall PEERENBOOM, China Modernizes: Threat to the West or Model for the Rest? (Oxford: Oxford University Press, 2007).
} 
new trajectory of Chinese diplomacy, which, as discussed above, is expected to become more "enterprising and innovative". ${ }^{4}$

In this context, actively participating in peacekeeping operations contributes to enhance the international image of China as a country committed to take concrete action in order to preserve peace and protect human lives. ${ }^{45}$ The fact that peacekeeping missions operate within the UN collective security system further allows China to (try to) build a reputation as a country which puts its faith in multilateral action based on shared rules of international conduct. The rhetoric that has developed around this commitment is well captured in the 2020 White Paper on UN peacekeeping, according to which Chinese armed forces participate in international security operations because China is determined to pursue world peace, protect people, and honour its responsibilities as a major country. ${ }^{46}$ At the same time, one should not forget that China's commitment to protect human lives through actively engaging in peace operations inevitably exposes it to a number of concrete risks, related, in particular, to fatalities, potentially prompting a reassessment of the calculations of the costs and benefits deriving from participating in peacekeeping, ${ }^{47}$ and poor performance which can, potentially, lead to significant reputational damage. ${ }^{48}$

Certainly, peacekeeping has limits as an instrument to pursue foreign policy objectives. For example, peacekeepers are only able to carry out the specific and narrowly defined mandates established by the UN Security Council. More importantly, they do not follow the instructions of the sending country but, instead, operate under the command and control of the UN. That said, as a permanent member of the Security Council, China has the capacity to influence at least some aspects of a mission's mandate to better suit its interests, as happened in 2014, when Beijing successfully demanded that the blue helmets deployed to South Sudan should also protect civilian workers in oil installations. ${ }^{49}$ A country like China could also shape the direction of particular missions by successfully placing its own nationals in a civilian or military position of command ${ }^{50}$ or, more generally, seek to reconfigure the priorities of peace operations with a view, for example, to elevating development as a central pillar of peacekeeping efforts. ${ }^{51}$ In an important sense, then, the advantage of actively participating in peacekeeping is the potential for pursuing (some) national strategic objectives in the context of multilateral, UN-led, and UN-authorized security operations that are more likely to earn praise than they are to raise suspicion. To this, one should add the fact that taking an active role in peacekeeping provides Beijing with an important opportunity to improve its armed forces' combat readiness and capabilities. This is all the more important considering the chinese

\footnotetext{
${ }^{44}$ Exploring the Path of Major-Country Diplomacy with Chinese Characteristics, supra note 28.

${ }^{45}$ For a broader discussion of China's engagement with human protection activities within the UN, see Rosemary FOOT, China, the UN, and Human Protection: Beliefs, Power, Image (Oxford: Oxford University Press, 2020).

${ }^{46}$ China's Armed Forces: 30 Years of UN Peacekeeping Operations, supra note 1.

${ }^{47}$ Jeremy PAGE and Matina STEVIS, "China Discovers the Price of Global Power: Soldiers Returning in Caskets" Wall Street Journal (15 November 2016), online: Wall Street Journal <https://www.wsj.com/articles/china-discovers-the-price-of-global-power-soldiers-returning-in-caskets-1479250248>. See also, Andrew LEVIN, "Peacekeeper Fatalities and Force Commitments to UN Operations" (2021) 38:3 Conflict Management and Peace Science 292.

${ }^{48}$ See, for example, Executive Summary of the Independent Special Investigation into the Violence in Juba in 2016 and the Response by the United Nations Mission in South Sudan, UN Doc. S/2016/924 (2016).

${ }^{49}$ Colum LYNCH, "U.N. Peacekeepers to Protect China's Oil Interests in South Sudan" Foreign Policy (16 June 2014), online: Foreign Policy <https://foreignpolicy.com/2014/06/16/u-n-peacekeepers-to-protect-chinas-oilinterests-in-south-sudan/>.

${ }^{50}$ Kseniya OKSAMYTNA, Vincenzo BOVE, and Magnus LUNDGREN, "Leadership Selection in United Nations Peacekeeping" (2021) 65 International Studies Quarterly 16.

${ }^{51}$ Foot, supra note 45.
} 
army's comparative lack of real war experience and the fact that China's defence strategy is currently informed by the belief that without a strong military, a country can be neither safe nor strong. ${ }^{52}$

\section{China and the Legal Architecture of UN Peacekeeping}

The first part of this article has highlighted the factors that contribute to explain China's endorsement of offensive and intrusive peacekeeping operations, despite the apparent incompatibility of the latter with Beijing's typically restrained foreign policy. The fact remains, however, that China must avoid setting any trend, particularly in politically sensitive areas, which could weaken the credibility of its professed adherence to the principles of sovereignty, non-intervention, and non-use of force in international relations. There is no doubt that China has an overriding interest in safeguarding the sanctity of these principles in the international legal system. By respecting them, Beijing preserves its capacity to use those same principles as legal tools to protect itself against foreign attempts to meddle in its internal affairs. This is particularly important for a country that not only faces constant external pressure regarding its model of society, but is also confronted with security-related challenges that have both a domestic and an international dimension.

The tension between supporting more offensive and intrusive peace operations on the one hand, and China's defensive foreign policy stance on the other, is reflected in the ambivalent way in which China approaches the principles that have traditionally defined the legal architecture of UN peacekeeping, namely: consent of the parties, impartiality, and non-use of force except in self-defence. The continued existence of these principles as guiding principles of UN peacekeeping is not under any concrete threat. Their importance has been reaffirmed, not only by influential UN documents concerning the strategy and doctrine of peacekeeping ${ }^{53}$ but also by the very Security Council's resolutions that established, among others, the mandates of the missions discussed in this article; that is MINUSCO, MINUMA, and UNMISS. At the same time, the interpretation of these principles had to be adjusted in the face of new circumstances and challenges. For example, the meaning of impartiality and limited use of force had to change in light of the nature of protection of civilians mandates. Even these new expanded interpretations, however, struggled to keep up with changes on the ground. In particular, the recent deployment of peacekeeping forces in the Democratic Republic of the Congo and Mali, authorized to launch offensive operations against specific armed groups, has raised questions about the compatibility of these operations and the very idea of impartiality and defensive force.

Against this background, states have to ponder the implications, risks, and opportunities stemming from particularly offensive forms of peacekeeping. Some have not shown great concern about the consequences of (over)stretching the meaning of the classic principles of peacekeeping. For these states, which include those that have always privileged a more militarized version of peacekeeping, as well as those that have benefited from the establishment of robust missions, what ultimately matters is that peacekeepers are capable of responding to the practical challenges faced on the ground. ${ }^{54}$ For other states,

\footnotetext{
${ }^{52}$ See, for example, "Xi Jinping's Report at $19^{\text {th }}$ CPC National Congress" Xinhua (18 October 2017), online: Xinhua <http://www.xinhuanet.com/english/special/2017-11/03/c_136725942.htm>.

${ }^{53}$ Brahimi, supra note 9; Capstone, supra note 4; and Report of the High-Level Independent Panel on Peace Operations on Uniting our Strengths for Peace: Politics, Partnership and People, HIPPO, UN Doc. A/70/95-S/2015/446 (2015) ("HIPPO").

${ }^{54}$ See, for example, William FLAVIN and Chiyuki AOI, "US Military Doctrine and the Challenges of Peace Operations" in Cedric DE CONING, Chiyuki AOI, and John KARLSRUD, eds., UN Peacekeeping Doctrine in a New
} 
however, eroding the significance of the basic principles threatens the core values of peacekeeping, blurs the line between peace operations and enforcement action, and increases the security risks associated with each mission. ${ }^{55}$

China is among the states that subscribes to the latter view. While Beijing has been somewhat receptive to calls for innovation in peacekeeping, largely because of the higher security risks involved in contributing troops to present-day missions, ${ }^{56}$ it has kept, formally, a firm position on the necessity that peacekeepers continue to fulfil their mandates under the principles of consent of the parties, impartiality, and non-use of force except in self-defence. ${ }^{57}$ Accordingly, the remaining part of the article will examine the extent and nature of the growing gap between Beijing's rhetoric, aimed at defending a traditional model of peacekeeping, and practice, which shows support for both offensive and intrusive operations.

\section{A. Consent of the Parties}

From a Chinese perspective, the consent of the parties is without any doubt the most important principle of peacekeeping. This is even more so in light of the recent changes that have affected its meaning. Traditionally, peace operations were deployed with the consent of the main parties to the conflict, a requirement which aimed to allow peacekeepers to perform their tasks freely and effectively. ${ }^{58}$ However, when UN missions began to be deployed in unstable settings, characterized by the presence of armed groups and other spoilers with different and often competing agendas, obtaining the consent of all the parties became increasingly unrealistic. ${ }^{59}$ This led to a de facto reinterpretation of the principle. Today it is widely accepted that, whereas the UN should seek to obtain the consent of all the main parties whenever is possible to do so, what ultimately matters is that it obtains the consent of the host state.

For China, the notion of consent is particularly important for two reasons. Firstly, because it defines a non-intrusive model of peacekeeping which, in line with Beijing's State-centric approach to international relations, is fully respectful of the principles of sovereignty and non-intervention. Secondly, because being a legal prerequisite to the deployment of a peacekeeping force, the host state consent marks a fundamental

Era: Adapting to Stabilisation, Protection and New Threats (London: Routledge, 2017), 33 and Alexandra NOVOSSELOFF and Thierry TARDY, "France and the Evolution of the UN Peacekeeping Doctrine" in Cedric DE CONING, Chiyuki AOI, and John KARLSRUD, eds., UN Peacekeeping Doctrine in a New Era: Adapting to Stabilisation, Protection and New Threats (London: Routledge, 2017), 90.

${ }^{55}$ For example, consider the position of countries such as Russia, Pakistan, Thailand, Vietnam, and Indonesia on the occasion of the 2014 Security Council debate on UN Peacekeeping Operations: New Trends, 7196th Meeting, UN Doc. S/PV.7196 (2014). See also, Seun ABIOLA, Cedric DE CONING, Eduarda HAMANN, and Chander PRAKASH, "The Large Contributors and UN Peacekeeping Doctrine" in Cedric DE CONING, Chiyuki AOI, and John KARLSRUD, eds., UN Peacekeeping Doctrine in a New Era: Adapting to Stabilisation, Protection and New Threats (London: Routledge, 2017), 152.

${ }^{56}$ In this regard, it is telling that, in April 2021, China, together with Brazil, Indonesia, and Rwanda launched the Group of Friends on the Safety and Security of UN Peacekeepers, at Ministry of Foreign Affairs of the People's Republic of China, "China and over 40 Countries Jointly Establish the Group of Friends on the Safety and Security of UN Peacekeepers" (27 April 2021).

${ }^{57}$ See, for example, Ministry of Foreign Affairs of the People's Republic of China, "Statement by Ambassador MA Zhaoxu at the Security Council Debate on UN Peacekeeping Operations" (28 March 2018); Position Paper of the People's Republic of China for the 72nd Session of the United Nations General Assembly, supra note 19; Draft Report on the Substantive Session of 2017, Special Committee on Peacekeeping Operations, 253rd Meeting, UN Doc. A/ AC.121/2017/L.3 (2017), at para. 27; and Draft Report on the Substantive Session of 2020, Special Committee on Peacekeeping Operations, 265th Meeting, UN Doc. A/AC.121/2020/L.3 (2020), at para. 26.

${ }^{58}$ Capstone, supra note 4 at 31.

${ }^{59}$ Ibid., at 32. 
difference between peace operations on the one hand and enforcement action authorized by the Security Council under Chapter VII of the UN Charter on the other. ${ }^{60}$ The latter involves military operations targeted normally at an "enemy" state whose conduct is deemed to pose a threat to international peace and security. The fact that these military operations are imposed against a state is what makes them particularly unattractive to China. For this reason, Beijing has always been wary of the risk of conflating these two forms of collective security. Some confusion in this respect is created by the Security Council's practice of establishing peacekeeping mandates in the context of Chapter VII resolutions. This is what the Security Council did, for example, when it created the mandates of MINUSCO, MINUSMA, and UNMISS. The simultaneous reference in these resolutions to both Chapter VII and the principles of peacekeeping raises important legal questions, given that combat troops are either deployed to perform peacekeeping duties or to carry out enforcement action, not both. To make sense of this apparent contradiction, various solutions have been proposed. Some have suggested that by using Chapter VII the Security Council acknowledges the seriousness of the situation and leaves open the possibility of relying, if necessary, on enforcement action. ${ }^{61}$ Others have highlighted that Chapter VII mandates provide greater legitimacy to the relevant peace operations, especially when they are directed at parties that do not recognize the government's authority. ${ }^{62}$ It has also been noted that the binding nature of a Chapter VII resolution enhances the stability of a mission by guaranteeing its continued functioning until the end of the mandate, even if the host state were to suddenly withdraw its previously given time-limited consent. ${ }^{63}$ None of these interpretations alters the actual nature of the relevant operations, which remain best described as peace operations guided by the basic principles of peacekeeping. The fact that, for example, none of the Chapter VII resolutions establishing the mandates of MINUSCO, MINUSMA, and UNMISS had the effect of circumventing the requirement for host state consent vindicates this view. For this reason, China seems now generally comfortable with the presence of Chapter VII elements in peacekeeping mandates.

Having clarified this preliminary point, it is now possible to uncover the nuances of the way in which the principle of consent is applied in practice. Consent is not only a dynamic concept but also one that is better measured on a scale of degree. ${ }^{64}$ For example, a state may accept the deployment of a peacekeeping force in its territory while expressing serious reservations about the terms of the relevant mandate or, a state may accept both the deployment and mandate of a mission, but lack the necessary commitment to work towards the broader political goals set by the UN. ${ }^{65}$ In each of these situations, a different

\footnotetext{
${ }^{60}$ Alexander ORAKHELASHVILI, “The Legal Basis of the United Nations Peacekeeping Operations” (2003) 43:2 Virginia Journal of International Law 485.

${ }^{61}$ Nicholas TSAGOURIAS, "Consent, Neutrality/Impartiality and the Use of Force in Peacekeeping: Their Constitutional Dimension” (2006) 11:3 Journal of Conflict and Security Law 465 at 471-3.

${ }^{62}$ Nico KRISCH, “Article 42” in Bruno SIMMA, Daniel-Erasmus KHAN, Georg NOLTE, Andreas PAULUS, and Nikolai WESSENDORF, eds., The Charter of the United Nations: A Commentary, Volume II, 3rd ed. (Oxford: Oxford University Press, 2012), 1330 at 1344.

${ }^{63}$ The host state is in any case entitled to withdraw its consent at the end of the mandate, a circumstance which would force the peacekeepers to leave its territory. Mona Ali KHALIL, "Legal Aspects of the Use of Force by United Nations Peacekeepers for the Protection of Civilians" in Haidi WILLMOT, Ralph MAMIYA, Scott SHEERAN, and Marc WELLER, eds., Protection of Civilians (Oxford: Oxford University Press, 2016), 205 at 219. On the issue of "change in circumstances", see Antonietta DI BLASE, "The Role of the Host State's Consent with Regard to Non-Coercive Actions by the United Nations" in Antonio CASSESE, ed., United Nations Peacekeeping: Legal Essays (Leiden: Brill, 1978), 55 at 58-69.

${ }^{64}$ Patryk LABUDA, "With or Against the State? Reconciling the Protection of Civilians and Host-State Support in UN Peacekeeping”, International Peace Institute, May 2020.

${ }^{65}$ Sofia SEBASTIÁN and Aditi GORUR, U.N. Peacekeeping \& Host-State Consent: How Missions Navigate Relationships with Governments (Washington: Stimson Center, 2018).
} 
type and degree of consent will materialize. For the purposes of this article, special attention must be paid to those instances where a particularly weak form of consent exists. This is so because the weaker the consent to the presence and activity of peacekeepers is, the more difficult it becomes to reconcile peace operations with the principles of sovereignty and non-intervention. Situations in which a state resents a peacekeeping force, but ultimately consents to it out of necessity, for example because it considers it instrumental to restore its authority over certain parts of the territory, do not pose a real threat to the sovereignty of that state. By contrast, cases of induced-consent raise more complex questions in that they blur the line between consensual and non-consensual forms of assistance/intervention to such an extent that distinguishing between them becomes almost impossible.

A crucial difference between situations of strong and weak consent follows from the above. While a peace operation that enjoys strong consent respects the principles of sovereignty and non-intervention, both in formal and substantive terms, one which has been accepted by a state solely because of external pressure, complies with those principles formally, but not substantively. Given that Beijing rhetorically portrays consent as a fundamental principle from which no derogation or exception is permitted, it should be very wary of the (non-infrequent) practice of inducing consent. ${ }^{66}$ Yet, China has not always applied the parameters of this principle rigidly. On some occasions it supported the deployment of peacekeeping missions that had only been accepted by the host state following external pressure, ${ }^{67}$ while on others it used its own leverage to facilitate that acceptance. ${ }^{68}$ Its recent involvement in the conflict in South Sudan illustrates this ambivalence very clearly.

As a result of its earlier economic engagement with Sudan, China invested significantly in the South Sudanese oil sector since day one of the country's independence. ${ }^{69}$ Beijing's friendship and close economic ties with both Sudan and South Sudan gave China a unique perspective on a crisis that was aggravated by the difficult oil-based relationship between Juba and Khartoum. Against this background, the conflict that broke out in December 2013, between President Kiir's forces and forces allied to former Vice President Machar, not only threatened the political and economic viability of what was already a fragile state, but also risked frustrating the political and financial capital invested by China in the country. This meant that Beijing had little choice but to get directly involved in this complex crisis, notably a development that, in the words of China's then special representative on African Affairs, marked "a new chapter for Chinese foreign affairs". ${ }^{70}$ This should not be taken to suggest that China played a leading role in multilateral meditation efforts. Yet, quite remarkably, Beijing not only followed very closely the evolution of the situation, but also actively participated in peace talks and negotiations with national, regional, and international parties.

One of the problems encountered by those seeking to find a solution to the crisis was the attitude of the South Sudanese government towards the offer of UN assistance. For

\footnotetext{
${ }^{66}$ Ian JOHNSTONE, "Managing Consent in Contemporary Peacekeeping Operations" (2011) 18:2 International Peacekeeping 168.

${ }^{67}$ Nicholas J. WHEELER and Tim DUNNE, “East Timor and the New Humanitarian Interventionism” (2001) 77:4 International Affairs 805.

${ }^{68}$ Andrew NATSIOS (Former US Envoy to Sudan), "Testimony on Sudan before the House Committee on Foreign Affairs" U.S. Department of State Archive (8 February 2007), online: U.S. Department of State Archive <https://2001-2009.state.gov/p/af/rls/rm/80294.htm>.

${ }^{69}$ International Crisis Group, "China's New Courtship in South Sudan: Africa Report N¹86” (4 April 2012), online: Refworld <https://www.refworld.org/docid/4f82fobe2.html>.

${ }^{70}$ Michael MARTINA, "South Sudan Marks New Foreign Policy Chapter for China: Official" Reuters (11 February 2014), online: Reuters <https://www.reuters.com/article/idUSBREA1A0HO20140211>.
} 
example, when UNMISS was initially established to help stabilize the newly created country, ${ }^{71}$ some governmental officials saw it as a form of "foreign babysitting" threatening South Sudan's sovereignty. ${ }^{72}$ Resentment towards the UN mission grew as the mandate of the latter expanded. In 2014, the nature of UNMISS changed significantly, in response to the eruption of the civil war and the growing evidence that atrocity crimes had been committed also by government forces. ${ }^{73}$ Against this background, Security Council resolution 2155 mandated UNMISS to proactively protect civilians under threat of physical violence "irrespective of the source", signalling a lack of trust in a government which the UN could no longer directly support. ${ }^{74}$ While it did not object to the mission altogether, South Sudan expressed reservations about the new tasks, urging the UN to refocus UNMISS on state-building. ${ }^{75}$ China voted in favour of the resolution and, as noted earlier, successfully demanded that peacekeepers be also authorized to protect oil installations.

Further cracks gradually appeared in the South Sudan-UNMISS relationship. For example, when, in 2015, the Security Council renewed the mandate of the mission, ${ }^{76}$ the representative of South Sudan highlighted the lack of his government's consent to important elements of the resolution, such as the deployment of unmanned aerial vehicles and the threat of sanctions and other punitive measures. ${ }^{77}$ Despite these objections, and the fact that states such as Russia and Bolivia condemned the resolution as an attack on South Sudan's sovereignty, China felt comfortable enough to support it. ${ }^{78}$

The tension between South Sudan on the one hand and UNMISS and the Security Council on the other reached its peak in the summer of 2016, when renewed fighting in Juba raised fears of a return to civil war. ${ }^{79}$ In response, the Security Council further reinforced the already robust mandate of UNMISS by establishing a regional protection force authorized to use all necessary means, "including undertaking robust action", to provide a secure environment in and around the capital. ${ }^{80}$ South Sudan did not consent to the creation of the special force, describing it as a violation of its sovereignty, territorial integrity, and political independence. ${ }^{81}$ This time, China joined other Security Council members, namely Russia, Bolivia, and Egypt, in abstaining on the resolution. That said, it stopped short of criticizing the Security Council for pushing through the resolution without South Sudan's agreement, referring, in less confrontational terms, to the importance for the regional protection force to eventually consult and obtain the consent of the national government. ${ }^{82}$ In accordance with its peacekeeping nature, the special force

\footnotetext{
${ }^{71}$ Security Council Resolution 1996, UN Doc. S/RES/1996 (2011).

${ }^{72}$ Hilde F. JOHNSON, South Sudan: The Untold Story from Independence to Civil War (London: I.B. Tauris, 2018) at 99-100.

${ }^{73}$ Conflict in South Sudan: A Human Rights Report, Report of the United Nations Mission in the Republic of South Sudan (UNMISS) (2014).

74 Security Council Resolution 2155, UN Doc. S/RES/2155 (2014).

${ }^{75}$ Reports of the Secretary-General on the Sudan and South Sudan, 7182nd Meeting, UN Doc. S/PV.7182 (2014).

${ }^{76}$ Security Council Resolution 2241, UN Doc. S/RES/2241 (2015).

${ }^{77}$ Reports of the Secretary-General on the Sudan and South Sudan, 7532nd Meeting, UN Doc. S/PV.7532 (2015).

${ }^{78} \mathrm{Ibid}$.

${ }^{79}$ Jason BURKE, "More than 300 Dead as South Sudan Capital is Rocked by Violence" The Guardian (11 July 2016), online: The Guardian <https://www.theguardian.com/world/2016/jul/10/south-sudan-capital-juba-violence-salva-kiir>.

${ }^{80}$ Security Council Resolution 2304, supra note 14.

${ }^{81}$ Reports of the Secretary-General on the Sudan and South Sudan, 7754th Meeting, UN Doc. S/PV.7754 (2016) ("7754th Meeting"). See also the letter sent on behalf of the Transitional Government of National Unity to the President of the Security Council on 10 August 2016 at Response of the Transitional Government of National Unity to the Draft Mandate Renewal for the United Nations Mission in South Sudan Circulated on 7August 2016, UN Doc. S/2016/698 (2016), online: United Nations <https://undocs.org/pdf?symbol=en/s/2016/698>.

82 7754th Meeting, ibid.
} 
was not deployed until Juba formally accepted it. Yet, it is evident that this was a case of weak and non-genuine consent obtained under considerable pressure. Only after reluctantly agreeing to it, the government of South Sudan not only created "serious impediments to the deployment" of the force, ${ }^{83}$ but once operative it continued to obstruct it on the ground. ${ }^{84}$

Several factors may contribute to explain Beijing's conduct on this particular occasion. For example, China had economic and political incentives to promote stability in South Sudan, given its close relationship with the government and the important role that it was inevitably expected to play in the mediation efforts. Also important is the fact that the two regional actors actively engaged in the resolution of the crisis, namely the Intergovernmental Authority on Development and the African Union, fully supported the idea of establishing a robust peacekeeping mission. This is in line with China's perception that regional organizations can confer vital legitimacy on non-consensual forms of assistance/intervention. ${ }^{85}$ A final element may caution against drawing too broad a conclusion from China's supportive stance on UNMISS. At the time of independence, South Sudan was described as "a country without a State". ${ }^{86}$ Hopes of a better future were later dashed by a combination of weak governance, weak leadership, and weak institutions. ${ }^{87}$ A decade after independence, South Sudan remains an extremely fragile state, gripped by economic stagnation and instability, and plagued by a dire humanitarian crisis. ${ }^{88}$ Set against this background, the objections to some aspects of UNMISS raised by successive frail and internally divided governments lost much of their potential force as faith inexorably waned in the ability of the latter to re-establish peace and security in the country. All of this warns against overgeneralization, suggesting, instead, that China's position on non-purely consensual operations will vary according to the specific circumstances of each case. Yet, the case of South Sudan indicates that, due to its growing interests overseas, China might increasingly find itself in situations where the principle of consent will have to be approached with a good dose of pragmatism.

\section{B. Impartiality}

A central feature of the model of peacekeeping originally envisioned by the UN was its neutrality. In a typical scenario, peacekeepers would be deployed to maintain a ceasefire and support, without taking sides, the larger political process aimed at resolving a conflict between two parties. In the past twenty years, however, peacekeeping forces have been regularly operating in risky environments and volatile political contexts associated with intra-state conflicts and civil wars. The complexity of these situations, coupled with the variety of parties involved, has made neutrality increasingly difficult to maintain, especially when adhering to it could cost civilian lives. The peacekeeping doctrine took note of the new reality. Brahimi warned that treating all parties to a conflict in an equal manner, irrespective of the factual circumstances of each specific case, would

\footnotetext{
${ }^{83}$ Special Report of the Secretary-General on the Renewal of the Mandate of the United Nations Mission in South Sudan, UN Doc. S/2018/143 (2018), at 2-3, para. 6.

${ }^{84}$ Security Council Resolution 2514, UN Doc. S/RES/2514 (2020).

${ }^{85}$ Courtney FUNG, "Global South Solidarity? China, Regional Organisations and Intervention in the Libyan and Syrian Civil Wars” (2016) 37:1 Third World Quarterly 33.

${ }^{86}$ Johnson, supra note 72 at 17.

${ }^{87}$ African Union Peace and Security Department, "Final Report of the African Union Commission of Inquiry on South Sudan" (15 October 2015), online: Peace AU <https://www.peaceau.org/uploads/auciss.final.report.pdf>, at para. 325 .

${ }^{88}$ The World Bank, "The World Bank in South Sudan” (5 November 2021), online: The World Bank <https:// www.worldbank.org/en/country/southsudan/overview>.
} 
risk undermining both the principles of the UN Charter and the objectives of a mission's mandate. ${ }^{89}$ Capstone confirmed that impartiality should not be confused with neutrality as the latter could lead to inaction "in the face of behaviour that clearly works against the peace process". ${ }^{90}$ In line with these doctrinal developments, the Security Council has regularly authorized peacekeepers to take sides by targeting spoilers who pose a threat to civilians or seek to undermine a mission's mandate.

From a Chinese perspective, what matters is whether this new interpretation of impartiality may threaten the viability of the model of peacekeeping favoured by Beijing. In protection of civilians mandates, for example, peacekeepers may have to act against government forces when the latter are themselves responsible for threatening civilian lives. That this is not just a hypothetical scenario is confirmed by the 2014 mandate of UNMISS, discussed earlier. At the same time, peacekeepers would rarely engage in robust military action against government units. If necessary, they would, in the first instance, take preventive and non-coercive measures to deter the latter from posing a threat to civilians. ${ }^{91}$ Should these measures fail, they could use non-lethal force by, for example, positioning themselves between the civilians at risk and the host state security forces. ${ }^{92}$ Even if more forcible action were to become necessary, peacekeepers would not be in a position to launch a full-scale attack against the host state. Targeting the latter in such a strong and direct manner would in fact need to be re-categorized and re-authorized as enforcement action. ${ }^{93}$

It is also important to note that the most offensive missions established by the Security Council thus far have been instructed to act in support of government forces. For example, Security Council Resolution 2098 authorized the special intervention brigade within MONUSCO to use proactive force, "in support of the authorities of the Democratic Republic of Congo", to neutralize armed groups such as the 23 March Movement responsible for various forms of violence and destabilizing activities. ${ }^{94}$ Similarly, Security Council Resolution 2295 authorized MINUSMA to take robust action "in support of the Malian authorities" to anticipate, deter, and counter the serious threats posed by various terrorist groups operating in the area. ${ }^{95}$ Legitimate concerns can be raised with regard to the compatibility between these partisan operations and the neutral model of peacekeeping traditionally supported by the UN. That said, the trend towards a less impartial model of peacekeeping is not a real cause for concern for Beijing, given the typical progovernment nature of these operations. In this sense, this new interpretation of impartiality does not risk undermining the state-centric approach to peacekeeping favoured by China. On the contrary, supporting missions such as MINUSMA and MINUSCO, which target terrorist groups, sits well with China's objective of becoming an "important player on the international counter-terrorism front", ${ }^{96}$ an objective which, in turn, must be

\footnotetext{
${ }^{89}$ Brahimi, supra note 9 at para. 50.

${ }^{90}$ Capstone, supra note 4 at 33.

${ }^{91}$ United Nations Department of Peace Operations, "DPO Policy on the Protection of Civilians in United Nations Peacekeeping" (1 November 2019), online: United Nations Peacekeeping <https://peacekeeping.un.org/ sites/default/files/poc_policy_2019_.pdf>, at para. 61.

${ }_{92}$ Ibid., at para. 62.

93 Tsagourias and White, supra note 7 at 274.

${ }^{94}$ Security Council Resolution 2098, supra note 12.

${ }_{95}$ Security Council Resolution 2295, supra note 13.

${ }^{96}$ See, for example, Permanent Mission of the People's Republic of China to the UN, "Statement by Ambassador Wu Haitao at the Open Meeting of the Security Council on the Threats to International Peace and Security Caused by Terrorist Acts" (27 August 2019), online: MFA PRC <https://www.mfa.gov.cn/ce/ ceun//eng/hyyfy/t1692491.htm>. On China's position on peacekeeping forces contributing to strengthen countries' capacity-building on counter-terrorism, see, for example, the statement by Mr. Liu Jieyi in Maintenance
} 
understood in conjunction with Beijing's efforts to confer international legitimacy to its domestic anti-terrorism measures. ${ }^{97}$

\section{Non-Use of Force Except in Self-Defence}

When UN peacekeeping was first envisioned, it was imagined that peacekeepers would only use force if and when necessary in self-defence. Before long, it became clear that the ability to simply defend themselves against an attack would not always allow peacekeepers to achieve the goals set by their mission's mandate. This led to the definition of a new and broader concept of self-defence, later endorsed in UN peacekeeping doctrine, which included the use of force "in defence of the mandate". It is precisely the vagueness of the concept of "defence of the mandate" that has allowed peace operations to become more aggressive in practice while remaining formally aligned with the loose legal framework regulating their use of force. ${ }^{98}$ As noted earlier in this article, however, missions such as MONUSCO and MINUSMA have gone beyond the boundaries set by that legal framework by engaging in offensive military operations that appear hardly reconcilable even with a heavily stretched notion of self-defence. ${ }^{99}$

The establishment of these operations has placed China in a difficult position because the idea of peacekeepers using offensive force clashes with its conservative position on the principle of non-use of force in international relations. China favours a strict interpretation of the latter in all relevant areas of international law. For example, its stance on humanitarian intervention, regarded as a blatant violation of international law, is uncompromising. ${ }^{100}$ China also defends the classic interpretation of the right to selfdefence enshrined in Article 51 of the UN Charter, warning against the risk of abuse of the doctrine of anticipatory self-defence. ${ }^{101}$ Furthermore, Beijing also has reservations with regard to the use of force authorized by the Security Council, as demonstrated by its tentative commitment to the principle of the Responsibility to Protect. Without denying the ability of the Security Council to authorize military interventions to protect populations from atrocity crimes, China regards this form of enforcement action only as an

of International Peace and Security: Peace Operations Facing Asymmetrical Threats, 7802nd Meeting, UN Doc. S/PV.7802 (2016), at 24-6.

${ }^{97}$ See, for example, Ministry of Foreign Affairs of the People's Republic of China, "Remarks by Ambassador Zhang Jun at the Security Council Open Debate on the Threats to International Peace and Security Caused by Terrorist Acts" (12 January 2021), online: Permanent Mission of the Peoples' Republic of China to the UN <http://chnun.chinamission.org.cn/eng/chinaandun/securitycouncil/thematicissues/counterterrorism/202101/ t20210113_8417446.htm>.

${ }^{98}$ Scott SHEERAN, "The Use of Force in United Nations Peacekeeping Operations" in Marc WELLER, ed., The Oxford Handbook of the Use of Force in International Law (Oxford: Oxford University Press, 2015), 347.

${ }^{99}$ Charles T. HUNT, “All Necessary Means to What Ends? The Unintended Consequences of the 'Robust Turn' in UN Peace Operations” (2017) 24:1 International Peacekeeping 108; John KARLSRUD, “The UN at War: Examining the Consequences of Peace-Enforcement Mandates for the UN Peacekeeping Operations in the CAR, the DRC and Mali" (2015) 36:1 Third World Quarterly 40.

100 See, for example, statement by Mr. Shen Guofang in Security Council Resolutions, 4011th meeting, UN Doc. S/ PV.4011 (1999), at 8-9, and the statement made by Mr. Qin Huasun in General Assembly Official Records, fifty-fourth session, 27th Plenary Meeting, UN Doc. A/54/PV.27 (1999), at 11-3.

${ }^{101}$ See, for example, Ministry of Foreign Affairs of the People's Republic of China, "Statement by Ambassador Zhang Yishan on Cluster II (Freedom from Fear) of the Secretary-General Report 'In Larger Freedom: Towards Development, Security and Human Rights for All' at Informal Thematic Consultations of GA 59th Session" (22 April 2005), online: FMPRC <https://www.fmprc.gov.cn/ce/ceun/eng/xw/t192893.htm>. See, also, Permanent Mission of the People's Republic of China to the UN, "Remarks by Ambassador GENG Shuang at the Open Arria Formula Meeting 'Upholding the Collective Security System of the UN Charter: The Use of Force in International Law, Non-state Actors and Legitimate Self-defense"' (24 February 2021), online: MFA PRC $<$ https://www.mfa.gov.cn/ce/ceun//eng/hyyfy/t1856424.htm>. 
absolute last resort measure, which should be contemplated solely after all other peaceful solutions have failed. ${ }^{102}$

Of course, in all the scenarios depicted above, force is used against a state, whereas in peace operations it is used in the territory of a state with the consent of the latter. Yet, the considerations made in previous sections problematize this simplistic distinction, revealing why an intensification of force in peacekeeping could be problematic for China. For example, it was noted earlier that in protection of civilians mandates, peacekeepers may, if necessary, use force against government forces who pose a threat to civilians. In addition, strong and genuine consent does not always exist, so that there may be situations in which a state will find unwanted forces on its territory potentially engaged in robust military action. More generally, using offensive force and taking sides risks intensifying a conflict and making UN peacekeepers a party to the latter under international humanitarian law, with the consequence that they would become legitimate military targets. ${ }^{103}$ The potential relationship between peacekeeping and other parallel military operations further adds to the complexity of the case. In this regard, it is telling that MINUSMA was instructed by the Security Council to support French troops and a regional force, both engaged in parallel count-terrorism operations in the Sahel.

For all the above reasons, China has not openly supported the shift towards more offensive forms of peacekeeping. Its official position, instead, has been and continues to be that peacekeepers should only use defensive force in accordance with the classic principle of non-use of force, except in self-defence and defence of the mandate. ${ }^{104}$ Yet, in practice, the incentives that were discussed earlier have driven China to take a more flexible stance on the matter. The way in which Beijing has thus far endorsed offensive missions, however, points to a lack of consistency which could generate unwanted consequences. In the case of MONUSCO, for example, China resolved to expressly justify the deviation from its official position. Mirroring the language used by the Security Council in the resolution establishing the Force Intervention Brigade, it referred in its explanation of vote to the "exceptional" character of that unit and the fact that its creation did not set a precedent in the area. ${ }^{105}$ By contrast, in 2016 China endorsed the new mandate of MINUSMA without qualification. While it could be argued that, by means of its very nature, the MONUSCO intervention brigade represented a more direct challenge to the traditional defensive model of peacekeeping, it should not be forgotten that the type of counter-terrorism operations that the Security Council authorized MINUSMA to conduct are equally incompatible with the classic principles of peacekeeping, a point that has been recently highlighted also by the UN High-Level Independent Panel on Peace Operations. ${ }^{106}$ One could have, therefore, expected China to join states such as Russia and Uruguay in raising concerns about the offensive nature of those operations and/or emphasizing their exceptional character. ${ }^{107}$ Instead, China not only

\footnotetext{
${ }^{102}$ Andrew GARWOOD-GOWERS, “China's 'Responsible Protection' Concept: Reinterpreting the Responsibility to Protect (R2P) and Military Intervention for Humanitarian Purposes" (2016) 6 Asian Journal of International Law 89.

${ }^{103}$ Alex GILDER, “The Effect of 'Stabilization' in the Mandates and Practice of UN Peace Operations” (2019) 66 (1) Netherlands International Law Review 47 at 56-9.

${ }^{104}$ China's Armed Forces: 30 Years of UN Peacekeeping Operations, supra note 1. See, also, Position Paper of the People's Republic of China for the 72nd Session of the United Nations General Assembly, supra note 19, and statement by Mr. Zhang Jun in United Nations Peacekeeping Operations, 8612th Meeting, UN Doc. S/PV.8612 (2019), at $9-10$.

${ }^{105}$ Statement by Mr. Li Baodong in The Situation Concerning the Democratic Republic of the Congo, 6943rd Meeting, UN Doc. S/PV.6943 (2013), at 8.

${ }^{106}$ HIPPO, supra note 53 at paras. 119-23.

107 The Situation in Mali, 7727th Meeting, UN Doc. S/PV.7727 (2016).
} 
supported MINUSMA, but also dispatched combat troops to it. Similarly, when China abstained on the resolution establishing the regional protection force in South Sudan, it did so on the basis of the reservations raised by the host state rather than the appropriateness of the level of force authorized by the Security Council. ${ }^{108}$

The above suggests that China is in practice less preoccupied with endorsing offensive peacekeeping operations than its rhetoric suggests. This de facto endorsement, however, can have the effect of reinforcing the legitimacy of a more aggressive model of peacekeeping, notably a development that would not be seen favourably by China. To avoid this, Beijing could regularly qualify its support for offensive operations by reference to their exceptional character. Yet, doing so repeatedly would end up calling into question the credibility of its objection to the use of offensive force. In this sense, the elaboration of a more coherent strategy to the question of offensive peacekeeping is inevitably hampered by the tension that exists between China's political interests on the one hand and legal preferences/concerns on the other.

\section{Conclusions}

As a global economic power increasingly exposed to the risks and costs of conflicts around the world, China has naturally integrated into its foreign policy the question of instability in strategically important regions. In light of its non-confrontational nature, peacekeeping has been elected as an instrument capable of contributing to achieve the abovementioned objective without calling into question China's continued adherence to a noninterventionist foreign policy. Direct engagement in peacekeeping operations further allows China to project the image of a country committed to human protection, while offering its military an opportunity to improve its combat readiness. As this article has suggested, however, these benefits come with a number of challenges revolving around China's interpretation and application of the classic principles of peacekeeping.

The first set of challenges derives from the aggressive nature of the peace operations recently supported by China. Missions such as MINUSCO, MINUSMA, and UNMISS are authorized to use offensive, as opposed to defensive, force. In addition, MINUSCO and MINUSMA are instructed to target specific "enemies" rather than remaining impartial. Beijing can take comfort in the fact that peacekeepers are still deployed with the consent of the host state and are normally mandated to support the efforts of the latter in re-establishing peace and security. Furthermore, the fact that offensive force has mainly been used to counter terrorist threats suits China's ambition to become an important player in international efforts to combat terrorism. At the same time, an escalation in the use of force by non-impartial peacekeeping units, both in itself and in combination with the consequences attached to it, raises a number of issues for Beijing given its traditional foreign policy posture and professed commitment to a strict interpretation of the principle of non-use of force in international law. This is even more so, considering that several states and influential UN reports have warned against the type of offensive operations conducted by MONUSCO and MINUSMA. For these reasons, China has not formally endorsed the shift towards a more offensive form of peacekeeping, calling, instead, for the continued respect of the principles of impartiality and non-use of force except in selfdefence. This has created a visible gap between its rhetoric and practice that will be difficult to bridge given the nature and dynamics of the competing forces at play.

A second challenge is represented by the practical difficulties that China is likely to encounter in defending a purely consensual model of peacekeeping. Peacekeeping forces can only be deployed with the consent of the host state, notably a requirement that,

\footnotetext{
${ }^{108}$ Statement by Liu Jieyi in 7754th Meeting, supra note 81 at 5.
} 
distinguishing peacekeeping from enforcement action, guarantees the alignment of the former with broader notions of sovereignty and non-intervention. In practice, however, China has not always applied the parameters of consent in a very rigid manner, having endorsed and even participated in missions established against the will of the host state and later deployed in the absence of genuine consent. While engaging in not fully consensual operations may allow China to better defend its interests abroad in the face of host states' reluctance to accept the offer of UN assistance, Beijing will have to constantly balance the benefits deriving from supporting intrusive operations with their potential effects on its commitment to rigid interpretations of the principles of sovereignty and non-intervention in international relations.

Finally, the way in which China engages, as a permanent member of the Security Council, with modern peace operations will not only contribute to shape its identity as a great power increasingly engaged in conflict prevention and resolution, but can also have important implications for both the practice and doctrine of peacekeeping. In particular, China's continued support for offensive operations, especially when not qualified, could contribute to a process of legal validation of even more expansive interpretations of the principles of impartiality and non-use of force except in self-defence, while at a more practical level, and despite inevitable divergences of views and interests, its more active involvement in international peacekeeping efforts could provide the basis for a more fruitful collaboration with the other Permanent-Five in tackling contemporary global peace and security issues.

Acknowledgment. The author would like to thank Dr Wim Muller and the anonymous reviewers for their helpful suggestions.

Funding. None.

Conflict of Interest. The author declares no competing interests.

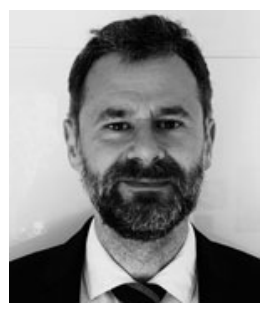

Dr Mauro Barelli is a Reader in Law at City, University of London, where he teaches Public International Law to LLB students and runs a course on Minority and Indigenous Peoples' Rights for LLM students. He studied for his LLB at the University of MilanoBicocca, obtained an LLM from the University of Bristol and earned his PhD from the University of Cardiff. He has been a visiting fellow at the Lauterpacht Centre for International Law, and a visiting lecturer at various institutions including the University of Nanjing and the University of Iceland. His research interests are in the fields of indigenous peoples' rights, the law on the use of force and Chinese perspectives on international law.

Cite this article: BARELLI M (2022). China and Peacekeeping: Unfolding the Political and Legal Complexities of an Ambivalent Relationship. Asian Journal of International Law 12, 157-176. https://doi.org/10.1017/ S2044251321000606 